\title{
Notes on the natural enemies of Etiella zinckenella in Puerto Rico'
}

\author{
Alejandro E. Segarra Carmona and Pedro Barbosa ${ }^{2}$
}

\begin{abstract}
Results from an Etiella zinckenella (Treit.) nafural enemy survey in Puerto Rico are presented. Egg parasitism by Trichogramma sp. was found to be very low $(3 \%)$. Six hymenopterous larval parasitoids were collected from larvae feeding on Crotalaria pallida (Ait.). Of these the braconid Heterospilus etiellae Rower was the most abundant species, accounting for $\mathbf{7 4 . 2} \%$ of parasitized larvae. Iconella etiellae (Vier.) was the only larval parasitaid recovered from soybeans. Overall percentage parasitism averaged $33.6 \%$, ranging from 5 to $91 \%$ at different locations. Notes are presented on the life history of the most eommon species. One experimenfal manipulation of accessibility of eggs to Solenopsis geminata (Fab.) failed to demonstrate any effect on $E$. zinckenella attack of $C$. pallida. Additional predators recorded include Polistes wasps and anole lizards. Strategies for utilization of these natural enemies are briefly discussed.
\end{abstract}

\section{INTRODUCTION}

The natural enemies of Etiella zinckenetla (Treit.) [the lima bean pod borer] are among the best known of Puerto Rican entomofauna. Two larval parasitoids, the braconid Heterospilus etiellae Rohwer and the chalcidid Eurytoma sp. were first reported by Leonard and Mills in 1931 (5). Wolcott $(11,12)$ provided notes on the biology of $H$. etiellae, adding Trichogramma sp. to the list of natural enemies of $E$. zinckenella. Introductions of five parasitoid species from Europe and North America were unsuecessfully attempted from 1936 to 1938 by Bartlett $(1,4)$. By 1948, Wolcott (13) had added the tachinid parasitoid, Argyrophylax sp. (cited as Agrophylax sp.) attacking $E$. zinckenella on Tephrosia toxicaria. However, questions still remain about additional predators and parasitoid-host plant relationships sometimes left unmentioned by these authors. Therefore, the main objectives of this study were to establish the identity and species composition of larval parasitoids on the borer's preferred wild host (Crotalaria spp.) and the economically important soybean (Glycine $\max$ L.). We also researched the possible role of well known predators such as ants and wasps in regulating borer populations.

'Manuscript submitted to Editorial Board 16 June 1987.

${ }^{2}$ Assistant Entomologist, Department of Crop Protection, College of Agricultural Seiences, University of Puerto Rico, and Professor of Entomology, Department of Entomology, University of Maryland. 


\section{MATERIALS AND METHODS}

We determined larval parasitoid abundance and identity by collecting green pods containing mature larvae from different localities from 198081. Pods were placed individually inside $1 \mathrm{oz}$. plastic cups. Attacked pods were easily recognized by their large areas of discoloration, usually covering more than $2 / 3$ of the pod's surface. Cups were checked daily until parasitoids or adult moths emerged. Specimens were sent to USDAIIBII Institute for identification by Dr. Lloyd Knutson. Observations on parasitoid behavior were obtained from field observations and laboratory dissections.

The role of ant predation on egg mortality was determined in an exclusion experiment. An $8 \times 8 \mathrm{~m}$ plot of $C$. pallida with 64 plants was established in 1983 at the Isabela Agricultural Experimental Substation, where Solenopsis geminata ( $\mathrm{Fab}$.) was abundant. Plants were sown $1 \mathrm{~m}$ apart. Twenty plants were randomly selected from this plot. From each plant 6 flower racemes (with no pods) were selected. A thick layer of tanglefoot adhesive was used to coat three racemes at their base to prevent ants from reaching the developing pods and eggs. The remaining 3 racemes served as checks. The adhesive was regularly checked for its effectiveness as a barrier and added as needed. Data were analyzed with the Nested ANOVA design on Statistical Analysis System.

\section{RESULTS AND DISCUSSION}

Egg parasitoids of E. zinckenella on Crotalaria pallida

Egg parasitoids were not common on eggs collected from $C$. pallida pods. Of 233 eggs examined, only 7 (3.0\%) contained Trichogramma sp. parasitoids. All specimens came from Isabela, Bo. Bajuras, a large plant patch (ca. 5,000 plants). This finding agrees with earlier observations on the rarity of this parasitoid on E. zinckenella from Puerto Rico (11).

\section{Larval Parasitoids and Notes on Their Biology}

Six species of larval parasitoids were found in patches of C. pallida. Two species were recovered from borer larvae feeding on $C$. incana, and one species was collected from C. anagyroides and C. zanzibarica, respectively. Parasitism rates varied widely from location to location. Rates ranged from 5 to $90.9 \%$ with an overall average parasitism rate of $34 \%$ for the island (table 1). No apparent differences in parasitism rates due to site elevation were observed.

The most common larval parasitoid found was Heterospilus etiellae Rohwer. This braconid was recorded attacking $E$. zinckenella from all susceptible Crotalaria species (i.e., C. pallida, C. incana, C. zanzibarica, and $C$. anagyroides). It was the dominant parasitoid in all $C$. pallida patches studied from 1980 and 1981 (table 1). Of 856 specimens of $H$. etiellae collected, $697(81.4 \%)$ were females. The average number 
TABLE 1.-Crotalaria pallida (Ait.) patches at three atitudinal levels and larval parasitoid species found at ench location, 1980-1981

\begin{tabular}{|c|c|c|c|}
\hline Location & $\begin{array}{l}\text { No. pods } \\
\text { examined }\end{array}$ & Parusitism & $\begin{array}{l}\text { Parasitoid spp.' } \\
\text { and (number of indiv.) }\end{array}$ \\
\hline \multicolumn{4}{|c|}{$\%$} \\
\hline \multicolumn{4}{|c|}{ Coustal or Low Elevation $(0-100 \mathrm{~m})$} \\
\hline Naguabo (Playa) & 10 & 30.0 & $\operatorname{He}(8), \operatorname{Eu}(1)$ \\
\hline Yabucoa (Roig) & 13 & 30.8 & $\mathrm{He}(20)$ \\
\hline Loíza Aldea & 38 & 52.6 & $\mathrm{He}(52)$ \\
\hline Piñones & 20 & 30.0 & $\mathrm{He}(42)$ \\
\hline Dorade (Mameyal) & 15 & 20.0 & $\mathrm{He}(14)$ \\
\hline Hatillo & 20 & 5.0 & $\mathrm{He}(2)$ \\
\hline Isabela (Playa) & 26 & 15.4 & He(38) \\
\hline Isabela (Jobos) & 48 & 29.2 & $\mathrm{He}(27), \operatorname{Ie}(3), \mathrm{Ch}(1)$ \\
\hline & & & $\operatorname{Eul}(1), \operatorname{Eu} 2(3), \operatorname{Ep}(1)$ \\
\hline \multicolumn{4}{|c|}{ Middle Elevations $(100-500 \mathrm{~m})$} \\
\hline Caguas (Cañaboncito) & 14 & 21.4 & $\mathrm{He}(10), \mathrm{Ie}(1)$ \\
\hline Patillas & 7 & 57.1 & $\mathrm{He}(17)$ \\
\hline Villalba (Toa Vaca) & 21 & 19.0 & $\mathrm{He}(2 A)$ \\
\hline Villalba (.own) & 25 & 44.0 & $\operatorname{Eul}(14), \mathrm{He}(5)$ \\
\hline Utuado (town) & 15 & 6.7 & $\mathrm{He}(7)$ \\
\hline Camuy (Bayaney) & 48 & 25.0 & $\operatorname{He}(83), \operatorname{Eu}(2)$ \\
\hline San Sebastián & 12 & 58.3 & $\operatorname{He}(18), \operatorname{Eu}\{(3)$ \\
\hline Moca (Las Marias) & 15 & 40.0 & $\mathrm{He}(38)$ \\
\hline Aguada & 11 & 90.9 & $\mathrm{He}(20), \mathrm{E} n 2(6), \operatorname{Ie}(2)$ \\
\hline Añasco & 35 & 48.6 & $\mathrm{He}(111)$ \\
\hline Añasco (Corcovarla) & 32 & 34.4 & $\operatorname{He}(50), \operatorname{Eu} 2(2)$ \\
\hline \multicolumn{4}{|c|}{ Higher Elevutions (wove $500 \mathrm{~m}$ ) } \\
\hline Maricao (Bucarabones) & 9 & 33.3 & $\mathrm{He}(24)$ \\
\hline Cidra & 23 & 30.4 & $\mathrm{He}(57)$ \\
\hline Orocovis & 16 & 6.3 & $\mathrm{He}(7)$ \\
\hline Jayuya & 23 & 47.8 & $\mathrm{He}(33), \mathrm{Eu2(4)}$ \\
\hline Adjuntas & 32 & 31.3 & $\mathrm{He}(24), \mathrm{Eu2}(3)$ \\
\hline \multicolumn{4}{|c|}{ Mean $=33.6 \pm 4.0 \%$} \\
\hline
\end{tabular}

${ }^{1} \mathrm{He}=$ Heterospilus etiellae, $\mathrm{Ie}=$ Iconclla etiellae, Eul = Eurytoma spl, Eu2 $=$ Eurytonta sp2, $\mathrm{Ch}=$ Chelonus $\mathrm{sp} ., \mathrm{Ep}=$ Chipelinus $\mathrm{sp}$.

of individuals emerging from an $E$. zinckenella larvae was $6.5 \pm 1.0$ (standard error) ( $n=130$ larvae). Both sexes emerged from senescent pods through small exit holes. These holes ( 1 to 4 per pod) appear in a group, usually near of directly above their cocoons. After paralyzing the larvae, parasitoid females deposit up to 18 eggs (mean=7.2 \pm 1.2 (SE) eggs per larva, $n=16$ larvae) in a cluster on the dorsal or lateral portions of the host epidermis. Eggs are elongated and creamy white, with an apical pedicel. All parasitized $E$. zinckenella larvae with eggs were late instar. Host larvae were frequently observed paralyzed but not oviposited by females. This phenomenon may lead to underestimation of this parasite's importance (10). 
Larvae reached maturity rapidly, usually in 3-5 days after oviposition. This finding agrees with that of earlier authors (11). H. etiellae exhibited all the typical characteristics of members of its subfamily (Doryctinae): ectoparasitic habits, paralysis of their hosts and rapid larval development (6). The whitish larvae commence eating as soon as they hatch, feeding in a group initially and scattering around the host larvae as they grow. Little remains eventually of the host, except its shriveled body and head capsule. Pupation occurs inside the pod, where mature larvae construct brownish cocoons in a clustered mass. The pupal stage, from 14-17 days, is of considerably longer duration than the larval stage. Flight dispersal is apparently very efficient in this delicate and small brownish wasp, which occurred almost anywhere that $E$. zinckenella appeared on $C$. pallida. This parasitoid accounted for $74.2 \%$ of parasitized larvae on $C$. pallida. However, it was never found on larvae feeding on other hosts of economic value, such as soybeans and pigeon peas.

Two species of Eurytoma were commonly found attacking $E$. zinckenella in C. pallida and C. incana patches, with $19.7 \%$ of all parasitized larvae attacked by these solitary ectoparasites (table 1). Adults of these species are dissimilar in appearance. These were designated as species 1 and 2 because of the lack of species identification. Species 1 is a small (ca. $1.5 \mathrm{~mm}$ ), black slender wasp found only occasionally. Immature stages of this species could not be observed. The plump reddish brown species 2 was more abundant and twice the size of species 1. The larvae of sp. 2 were plump and greenish white. They consumed $E$. zinckenella larvae in 4-6 days. This genus contains members with very diverse feeding habits. The role of these two species as possible facultative hyperparasitoids should be further explored. Both species were absent from soybeans at Isabela.

The last of the common parasitoids is the braconid Iconella (=Apanteles) etiellae (Vier.). This species has the most potential for biologically controlling $E$. zinckenella on soybean and perhaps on pigeon peas. This microgastrine is a solitary endoparasite of a variety of lepidopterous larvae, including other pod borers. It is distributed throughout North America and the Caribbean. It was found attacking $E$. zinckenella larvae on C. pallida and C. incana, accounting for $3.4 \%$ of all parasitized larvae in the former species. In C. pallida plots planted near soybean, $I$. etiella was responsible for up to $83 \%$ of all larvae being parasitized. In soybean, this parasitoid accounted for all observed parasitism. Much information is available about the biology of this species. Bennett (2) found that eggs were laid in Ancylostomia stercorea (Zeller) during the host early instars. The ability to be attracted to host plants in feral and agricultural environments makes this parasitoid a promising candidate for augmentation and biocontrol conservation efforts. 
Two additional larval parasitoids were found: the braconid Chelonus sp. and the eupelmid, Eupelmus sip. Only one sipecimen of Chelonus sp. and two of Eupelmus sp. were collected. Species identification could not be obtained. The genus Chelonus is an interesting one because of its habit of ovipositing the eggs of its insect host. Curiously, the mature endoparsitoid larvae emerge during the latter host instars (7). A Eupelmus sp. has been found as an hyperparasite of $I$. etiellae on $A$. stercorea boring in pigeon peas in Trinidad (2). Its role as a hyperparasitoid should be explored in future research.

\section{Effect of Solenopsis geminata as Egg Predators}

Extrafloral nectaries are often associated with ant-plant defense activities (3). Because of their presence in Crotalaria species, the possible role of ants as egg predators was briefly investigated. No significant differences in E. zinckenella pod attack rates, larvae per raceme, percentage of parasitized larvae, or number of pods per raceme could be detected between ant-excluded or control racemes (table 2). The experimental field contained a large population of Solenopsis geminata (Fab.), frequently observed feeding from the nectaries and tending aphids affixed on the raceme. S. geminata is a well known egg predator in Puerto Rico (9).

\section{Notes on Predation by Other Organisms}

Other enemies observed actively predating on $E$. zinckenella were Polistes spp. wasps and Anolis spp. lizards. Polistine wasps were frequently seen extracting larvae from the pods of C. pallida. The method used to gain access inside the pod was never observed. Anole lizards were active predators of both mature larvae and adults, attacking the former when the larvae exited from the pod to pupate in the soil. Lizards were frequently observed jumping from Crotalaria spp. plants to catch pod exiting larvae.

TABLE 2,-Resulls of the ant exclusion expriments of Crotalaria pallida and their effect on the plant and on Etiella zinckenella at the Isabela Exp. Res. Sin., May-August 1989 $($ mean $\pm S E$ )

\begin{tabular}{lccc}
\hline \multicolumn{1}{c}{ Variable } & $\begin{array}{c}\text { Excluded } \\
(\mathrm{N}=52 \text { racemes })\end{array}$ & $\begin{array}{c}\text { Not excluded } \\
(\mathrm{N}=52 \text { racemes })\end{array}$ & $\mathrm{P}$ \\
\hline Pods/raceme & $10.8 \pm 0.7$ & $11.0 \pm 0.7$ & $\mathrm{NS}^{\prime}$ \\
Larvae/raceme & $4.5 \pm 0.6$ & $3.4 \pm 0.4$ & $\mathrm{NS}$ \\
Parasitized larvae/raceme & $1.2 \pm 0.2$ & $0.9 \pm 0.2$ & $\mathrm{NS}$ \\
\% pod bored & $41.8 \pm 4.3 \%$ & $38.0 \pm 3.4 \%$ & $\mathrm{NS}$ \\
\% parasitized larvae & $30.4 \pm 3.1 \%$ & $23.9 \pm 2.8 \%$ & $\mathrm{NS}$ \\
\hline
\end{tabular}

'NS $=p>0.05$. 


\section{CONCLUSIONS}

There is a promising future for the manipulation of natural enemy populations of $E$. zinckenella in Puerto Rico. As more research is conducted on each natural enemy, more accurate assessments can be made of their usefulness. For the time being, augmentation and conservation efforts can be directed to increase population levels of 1 . etiellae, and Polistes wasps since methods for their rearing and conservation have been tried and tested elsewhere $(1,7,8)$. A second line of defense could be established by considering other parasitoids such as $H$. etiellae or Trichogramma sp., on agricultural legumes. Finally, possible natural enemies such as soil carabids and ants could be evaluated to institute further control of $E$. zinckenella.

\section{IRESUMEN}

\section{Apuntes sobre los enemigos naturales de Etiella zinckenella en Puerto Rico}

Este trabajo presenta los resultados de un reconocimiento de los enemigos naturales del barrenador Etiella zinckenella (Treit.). Solo se encontró Trichogramma sp. atacando una baja proporción (3\%) de los huevos de E. zinckenella. Se informan 6 parasitoides himenópteros atacando los estadios larvales. De estos parasitoides, el bracónido Heterospilus etiellae Rower fue el más importante; se encontró en el $74.2 \%$ de las larvas parasitadas. El porcentaje medio de parasitismo en las larvas del barrenador fue de $33.6 \%$ con valores entre 5 y $91 \%$ de diversas localidades. Sólo el bracónido Iconella etiellae pudo recobrarse de hospederos de importancia económica, como la soya. Se presentan apuntes sobre la historia natural de las especies parasíticas más comunes. Un experimento en el cual se manipuló el acceso de la hormiga Solenopsis germinafa (Fab.) a los huevos de $E$. zinckenella en plantas de la hospedera Crotalaria pallida no demostró ningún efecto sobre el ataque del barrenador. Se hallaron otros depredadores del barrenador, como las avispas del género Polistes y los lagartijos del género Anolis.

\section{LITERATURE CITED}

1. Bartlett, K. A., 1939. Biological control activities. P. R. Agric. Exp. Stn. Rep. (1938) pp. 94-109.

2. Bennett, F. D., 1960. Parasites of Ancylostomia stercorea (Zell.), (Pyralidae, Lepidoptera) a pod borer attacking pigeon pea in Trinidad. Bull. Entomol. Res. 50: $737-57$.

3. Bentley, B. L., 1977. Extrafloral nectaries and protection by pugnaceous bodyguards. Annu. Rev. Ecol. Syst. 8: 407-27.

4. Clausen, C. P., 1978. Introduced parasites and predators of arthropod pests and weeds; A world review. USDA Handb. 480.

5. Leonard, M. D. and S. A. Mills, 1931. A preliminary report on the lima bean pod borer and other legume pod borers in Porto Rico. J. Econ. Entomol. 24: 466-73.

6. Mathews, R. W., 1974. The biology of braconidae. Amu. Rev. Entomol. 19: 15-31. 
7. Rabb, R. L., 1971. Naturally-occurring biological control in the eastem United States, with particular reference to tobacco insects. In: Biological control, Ed, C. B. Huffaker. Plenum Press, N. Y.

8. - and F. R. Lawson, 1957. Some factors influencing the predution of Polistes wasps on the tobaceo hornworm. J. Econ. Enlomol. 50: 778-84.

9. Rickman, D. B., W. F. Buren and W. H. Whitcomb, 1984. Predatory arthropods attacking the eggs of Diapreppes abbrevialus (L.) in Puerto Rico. J. Ga. Entomol. Soc. 18: $335-42$.

10. van Driesche, R. G., 1983. Meaning of "Percent Parasitism" in studies of insect parasitoids. Environ. Entomol. 12: 1611-622.

11. Wolcott, G. N., 1933. The lima bean pod borer caterpillar of Puerto Rico. J. Agric. Univ. P. R. 17 (3): 241-55.

12. - 1984. Lima bean pod borer caterpillars of Puerto Rico on their wild hosts. $J$. Agric. Univ. P. R. 18 (3): 429-34.

13. - 1948. The insects of Puerto Rico. J. Agric. Univ. P. R. 32 (1-4): 599-601. 